\title{
Development of BIM (Building Information Modeling) concept applied to projects of Substations Integrated with the Geographic Intelligence System (GIS)
}

\author{
DIOGO MARTINS AZEVEDO \\ dept. of Electrical Engineering \\ Federal University of Uberlândia \\ Uberlândia, BRASIL \\ diogoma16@gmail.com \\ EDGARD LAMOUNIER \\ dept. of Electrical Engineering \\ Federal University of Uberlândia \\ Uberlândia, BRASIL \\ lamounier@ufu.br \\ CLAUDIO GUTTLER \\ dept. of Electrical Engineering \\ Furnas Centrais Elétricas S/A \\ Rio de Janeiro, BRASIL \\ guttler@furnas.com.br
}

\author{
ANA MAROTTI \\ dept. of Electrical Engineering \\ Furnas Centrais Elétricas S/A \\ Rio de Janeiro, BRASIL \\ amarotti@furnas.com.br
}

GERSON FLÁVIO M. DE LIMA

dept. of Electrical Engineering

Federal University of Uberlândia

Uberlândia, BRASIL

gersonlima@ieee.org

\author{
RICARDO DE OLIVEIRA ROCHA \\ dept. of Electrical Engineering \\ Furnas Centrais Elétricas S/A \\ Rio de Janeiro, BRASIL \\ rolivei@furnas.com.br
}

\author{
ALEXANDRE CARDOSO \\ dept. of Electrical Engineering \\ Federal University of Uberlândia \\ Uberlândia, BRASIL \\ alexandre@ufu.br
}

\author{
ANDRÉ LUÍS DE ARAUUJO \\ dept. of Archtecture \\ Federal University of Uberlândia \\ Uberlândia, BRASIL \\ andre.araujo@ufu.br
}

\author{
CLAUDIA BARTHOLOMEU \\ dept. of Electrical Engineering \\ Furnas Centrais Elétricas S/A \\ Rio de Janeiro, BRASIL \\ bartho@furnas.com.br
}

\begin{abstract}
In the context of the Brazilian electrical sector, there are no references regarding the application of BIM (Building Information Modeling) and GIS (Geographic Information System) in construction and maintenance of Electric Power Substations projects. Thus, this work proposes the integration of these technologies, since preview experiences in other engineering fields have shown promising advances that could be useful for the management and maintenance of the electrical power market. By associating these technologies, an accurate mapping of the information related to the assets, arrangements, cabling, bus, electrical components, etc, is obtained. Moreover, for this integration works, it is required to design a three-dimensional geometric database of the electric power substation active com-ponents. Inserting one of the database models into a particular point of the project shall bring constructive, operational, and maintenance information. Thus, by combining BIM and GIS in the modeled families, it is possible to obtain more consistent information during the construction phase. This will provide advantages in decision making, providing resources within the corporate communication, and a better understanding of the environment related to an electrical energy substation. Additionally, the location conditions and the surroundings of the substation would be more precise and pertinent, since the components of the substation will become Geo-referenced. The association between these two platforms allows a more intuitive overview of the project, making them adherent to the planning, design, construction, operation, preventive, and corrective maintenance. So, when applying these tools together the company will obtain results almost immediately since all managing features will be accessed through only one integrated information database. This proposal presents the first results of the integration of BIM and GIS, in the context of a Brazilian electric company - Furnas S/A. Results of the implementation of the solution in the context of Substations of the Company are discussed and show the availability of reducing construction costs, alteration planning, logistics, on-demand of the necessary maintenance, prevention of possible accidents, and possibility of updating information in real-time.
\end{abstract}

Keywords-Electric Power Systems, Building Information Modeling, Geographic Information System, Electrical Systems, Power Substation Received: August 11, 2020. Revised: December 15, 2020. Accepted: January 8, 2021. Published: February 7, 2021.

\section{Introduction}

The Rising power demand in the world means that there is a need to build new electric power substations or upgrade the existent. What is a challenge to AEC (Architecture, Engineering, and construction) Industry, since, it is necessary to design and manage more efficiently [1]. Hence, a possible way to do better management is a Building Information Modeling (BIM) integrated with Geographic Intelligence Systems (GIS). A possibility to do better management of Design on Substation is involved in the project's multi-disciplines in a single one [2]. As a result of this collaborative work the professionals and the Companies would have a better result in the Design and Construction [3]. However, substation design is a complicated 
process, which requires important analysis before the beginning of any design, finding an optimal solution, satisfying the standards [1]. Afterward, it is interesting to adopt strategies with BIM for the development of new electrical substations. Carrying these strategies, it is important to highlight that a good substation design can be supported by teamwork with multi-disciplinary capabilities working from different branches with BIM methodology (see Figure 1).

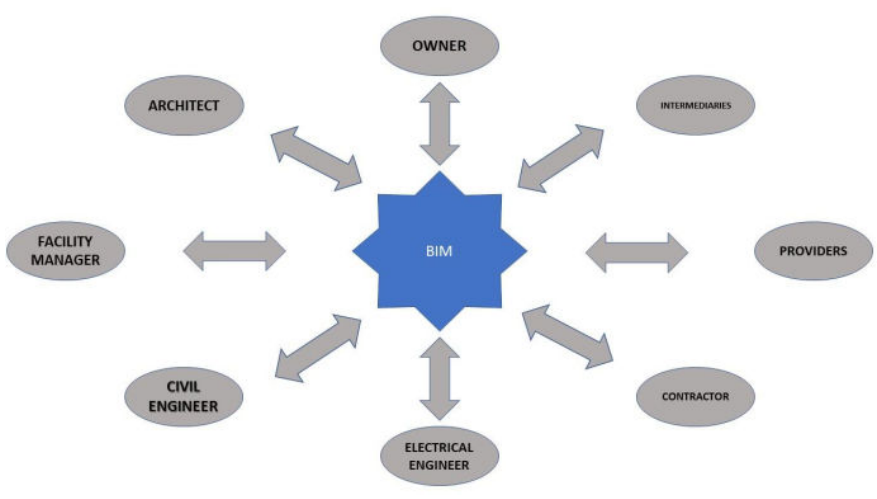

Fig. 1. Multi disciplinary teamwork (adapted from [1]).

Besides, it is possible to associate BIM with GIS for a complete management system, as has already been demonstrated in urban management [4]. Thus, it is easy to have more efficiency in management when these tools are applied together. However, as opposed to architecture and civil engineering, in the national electricity sector, there are no references regarding the application of BIM and GIS in construction and maintenance projects of electric power Substations. Therefore, this work deals with the integration of these technologies, which will point to innovative results in the area of engineering, maintenance, and operation of Electric Power Substations. This switching between the BIM and GIS methodology is only possible due to the collaborative characteristics of the BIM model [4]. Although this application already exists in the field of civil engineering, it is necessary to study more in depth the electric energy distribution sector, which is the object of this work, because, by associating these technologies, a map with high precision of the information related to the assets, arrangements, cabling and components of an electric power substation, directly influencing the logistics of equipment and maintenance teams, reducing costs for reworking substation projects, facilitating regulatory and approval procedures, integration with services, monitoring, supervision and inspection, value generation, and cost reduction with integrated procedures using BIM technology (see Figure 2).

\section{Building Information Modeling (BIM)}

According to Autodesk (2018), [6], BIM is an intelligent 3D model-based process that gives AEC professionals the insight and tools to more efficiently plan, design, construct and manage buildings infrastructure. This model brings a construction database, being possible to all branches involved

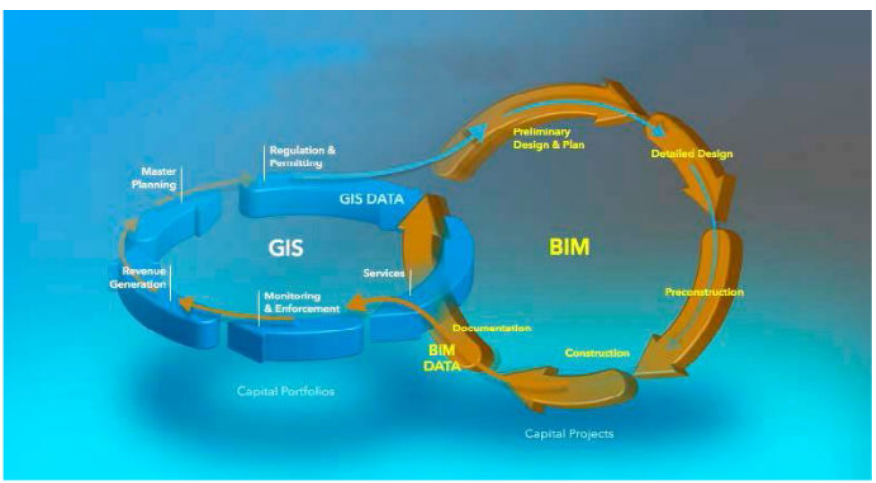

Fig. 2. Workflow BIM and GIS [23]

in the planning and execution checking information regarding HVAC (Heating, Ventilating, and Air Conditioning) [5]. BIM Methodology allows information sharing between the multi-disciplinaries teams, creating a Virtual Environment (VE) 3D of the blueprint. This VE allows the updating of the constructive information of the building [6]. Therefore, with this collaborative working environment become easier to identify critical factors in the planning phase, enabling better making decision in the design process, creating a $2 \mathrm{D}$ blueprint associated a $3 \mathrm{~d}$ model [7]. A BIM software gives the entire $3 \mathrm{~d}$ model in all its phase and in final integrated form, so there is a complete overview of planning and implementation and the output documentation has high quality because it provides insight into all elements necessary to make the decision (see Figure 3) [1].

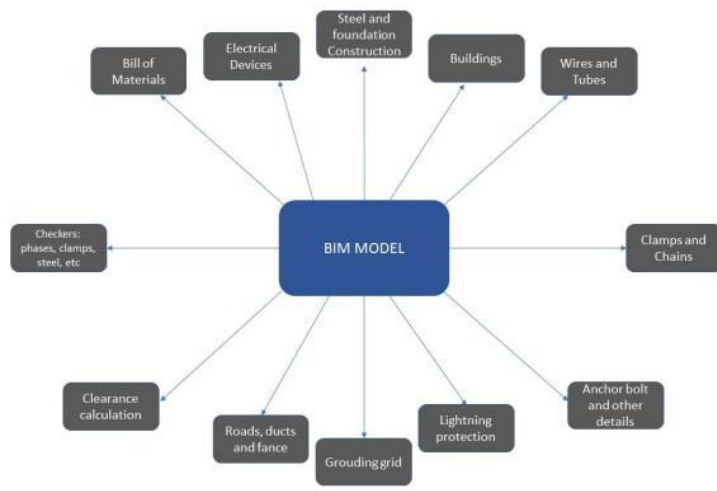

Fig. 3. Sample of a BIM model with a high Level of Detail (LoD).

Thus, by systematically applying the definitions and parameters to be standardized, it is possible to create a digital library with BIM substation objects for the use of several substation projects, making the digital models applied in these projects exceed a simple three- if a model 4D, 5D or $\mathrm{nD}$, [8]. Therefore, BIM is a Computer Supported Cooperative Work (CSCW), capable to generate collaborative models with simulation information, planning, design, construction, and operation, [9]. 


\section{Geographic Information System (GIS)}

GIS is a computerized database management system, which is capable to gather, store, recover, analyze and display georef-erenced information [10]. With the huge increase of service demands in the AEC Industry, it requires an improved way of information visualization to have a better making decision, [11]. Thus, for this GIS has already presented itself as a great tool for urban management [4] [12]. Geospatial information can be analyzed to determine the geographic location of predetermined attributes and their relationships to the regions of interest pointed out. As far as where such points of interest exist and quantify them, what happens in the area of interest and what happens in the surrounding regions so that it is possible to predict how a specific area changes with time, [13]. The geographic information system can be integrated into a database, which results in an intelligent program that analyzes the behavior of the area of interest in a more objective and summarized way, thus presenting information in the form of a map oriented more clearly to the operators and users of the system. In order to optimize the service provided and increase the quality of the product, GIS is able to assimilate all the parameters of the real environment into a single virtual model and, when associated with another platform that supports the map, make changes and simulations according to the requested project [14]. After defining the territory and constituting a sketch of the project to be implemented, the GIS performs a calculation of the polygons conferring the possibility of its execution by means of a geographical code that can be interpreted by several BIM software, how is possible to check in the workflow below (see Figure 4)

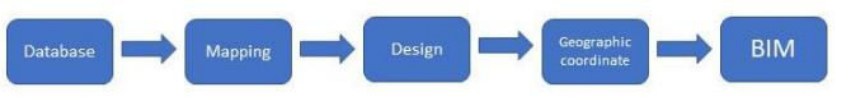

Fig. 4. Workflow of a GIS project.

By associating GIS data with three-dimensional (3D) models, all movement and organization of the Virtual Environment are progressively simulated. This correlation is possible because GIS analyzes the objects and points of interest that already exist in the environment in a more abstract way, opening the door to the entrance of another system that would construct a Virtual Environment on the real as an attachment, or be an intelligent platform that has the ability to model the VE on the mapping created [15]. BIM is associated to this aspect, complementing the service provided by the GIS, which has a focus on external modeling, such as areas of greater magnitude, in order to increase a physical project on the observed region through internal focus modeling, such as buildings [16]. To develop a BIMGIS association, it is essential that the benefits of both technologies be evidenced in a single understood model. GIS that creates from existing objects, and BIM that creates with intelligent constructs
TABLE I

COMPARISON BETWEEN BIM AND GIS

\begin{tabular}{|c|c|c|}
\hline & GIS & BIM \\
\hline $\begin{array}{l}\text { Modeling Envi- } \\
\text { ronment }\end{array}$ & $\begin{array}{l}\text { Focused on posi- } \\
\text { tioning and exter- } \\
\text { nal environment. }\end{array}$ & $\begin{array}{l}\text { Focused on inter- } \\
\text { nal environment. }\end{array}$ \\
\hline $\begin{array}{l}\text { Reference Sys- } \\
\text { tem }\end{array}$ & $\begin{array}{lr}\text { Geospatial } \\
\text { Data been } \\
\text { georeferenced. } \\
\text { Objects are } \\
\text { defined } \\
\text { physical in } \\
\text { with } & \text { world } \\
\text { coordinate } & \\
\text { system. } & \\
\end{array}$ & $\begin{array}{l}\text { BIM objects has } \\
\text { your own coordi- } \\
\text { nate system. }\end{array}$ \\
\hline Sketch Detailing & $\begin{array}{l}\text { Creates from } \\
\text { a preexisting } \\
\text { object. It covers } \\
\text { a larger area with } \\
\text { lower level of } \\
\text { detail and on a } \\
\text { smaller scale. }\end{array}$ & $\begin{array}{l}\text { Create in a large } \\
\text { scale with a big- } \\
\text { ger Level of De- } \\
\text { tail. }\end{array}$ \\
\hline Application & Urban Area & $\begin{array}{ll}\text { Singular } & \text { units } \\
\text { and } & \text { your } \\
\text { construction } & \\
\text { attributes } & \\
\end{array}$ \\
\hline 3D Models & $\begin{array}{l}\text { Used to } \\
\text { limited in a 2D } \\
\text { Model }\end{array}$ & $\begin{array}{l}\text { Use a 3D Model } \\
\text { Rich in details }\end{array}$ \\
\hline
\end{tabular}

with information [16]. It is also necessary to highlight the incompatibilities that may hinder the creative process but can be interpreted as an association of the boundaries of the two technologies (see Table I).

\section{Literature Review}

Inside this topic, will be approached works related to the proposed theme, as well as the differentiation of the current work of the other works raised. In order to reach the main scientific works on Building Information Modeling and Geographic Information System applied to projects of electric power substations, the following keywords were used: BIM, GIS, Substations of electric energy, and georeferencing. At the end of the searches, 3 papers were found and selected focusing on the BIM and GIS integration.

A. Integration of BIM and GIS to Query Management on pipeline of building-A case study of dormitory [21]

This paper applies BIM and GIS to manage pipelines for buildings, it was applied in a case study in a Dormitory for students. They use ArchiCAD software to depict the building and pipelines with object attributes and combine with SkylineTerraExplorer as GIS software, doing that they had a 3d pipeline. As a result of this research, they succeeded in better management of the pipelines.

B. CAD-GIS BIM Integration - the Case study of Banja Luka City Center [22]

This article provides an introduction of ongoing technology integration efforts targeting fields of Computer-Aided-Design 
(CAD) and drafting, Geographic Information System (GIS) and Building Information Modeling (BIM). To merge this software, there is a high demand for time being more effective if you can reuse the results of each project, that way been more effective this integration.

C. Integration of BIM and GIS: A tool for Urban Management [4]

The paper focuses on investigates how BIM and GIS intersection can contribute to creating an integrated system to attend public utilities and urban management offices for addressing accurate control on saturated and under-risk areas. The system will also attend designers and contractors, by enabling up-to-date public infrastructure network data to be accessed during the project phase.

\section{Comparison between the works}

It is possible to observe that the works presenting the integration of BIM with GIS are in the area of civil construction or information management, however, there is no such integration in the electric power distribution sector and electric power substations as can be seen in Table II:

TABLE II

TABle Type Styles

\begin{tabular}{|l|l|l|l|}
\hline Papers & BIM & GIS & $\begin{array}{l}\text { Electrical } \\
\text { Substation }\end{array}$ \\
\hline Chin Feng et al. & $\mathrm{X}$ & $\mathrm{X}$ & \\
\hline Nikolina Et al. & $\mathrm{X}$ & $\mathrm{X}$ & \\
\hline $\begin{array}{l}\text { Almeidaand } \\
\text { Andrade (2015) }\end{array}$ & $\mathrm{X}$ & $\mathrm{X}$ & \\
\hline This Paper & $\mathrm{X}$ & $\mathrm{X}$ & $\mathrm{X}$ \\
\hline
\end{tabular}

\section{Development}

This project is in the development phase and requires some steps for the evaluation of software for modeling and junction of the Geographic Information System and Construction Information Methods, for this, a compatibility analysis was performed between a modeling software, a BIM software and those of GIS.

The first step was select a Electromechanical Software for modeling the substation components. However, this software must be compatible with a BIM software or export in IFC (Industry Foundation Class) Format. For the development of this work was selected the Autodesk Invetor as Electromechanical modeling software, because, the software has a native communication with BIM software (E.g Autodesk Revit).

The second step was decide which BIM software would be used. To define that, be required a research of commercial software and in that research was defined to use the autodesk solution, by the large usage of this software in the world (figure 5). Besides, the communication between the electromechanical software and BIM software is direct, the inventor export in revit family format (RFA) without needing a plug-in.

Thereafter define the software, was developed a proposal of workflow (figure 6). With this workflow the Revit is the

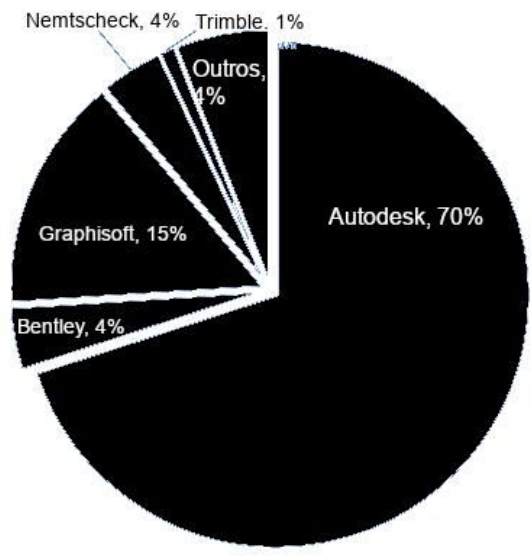

Fig. 5. Market of BIM software usage

center of all information as a "BIM Engine". Where all the information from the electromechanical models, GIS and SAP ERP (Enterprise Resource Planning).

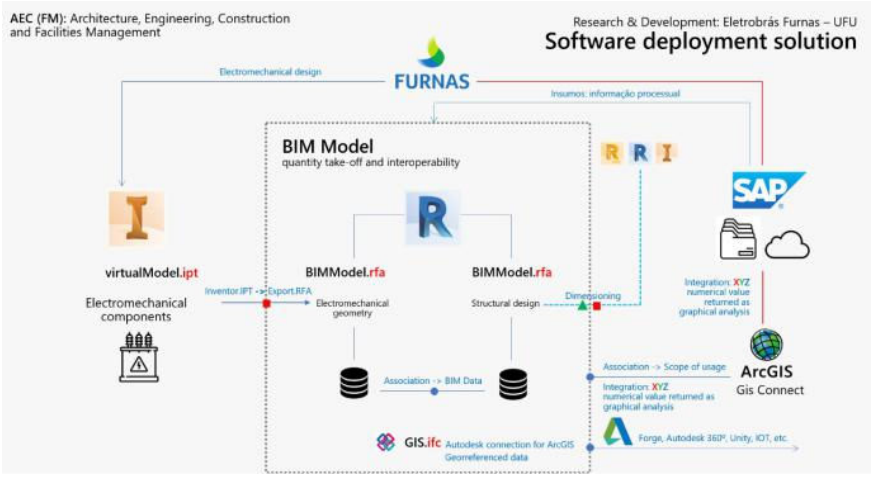

Fig. 6. Proposal of BIM-GIS Furnas workflow.

In this workflow all the proposal (figure 6) was in Autodesk solution, but is possible to use another softwares BIM since this software generate a file in the IFC format, which is a nonprofit neutral product, is exported, which is intended to support the life cycle of buildings, creating a pattern of The data set of ISO 16739, so-called interoperability in AEC (Architecture, Engineering and Construction), was published by the IAI (International Alliance for Interoperability) [3].

After the modeling phase and create the families, is necessary to define the communication between the GIS blue print with our $3 \mathrm{~d}$ model. Once the GIS is a a information without graphic return. Thereby the connection between these two technologies (BIM and GIS) is made in the coordinates of the model.

Therefore, the development of this project of application of BIM technologies in the area of electric power substations in conjunction with technologies of georeferencing has followed this workflow: Determine a software to create the electromechanical model, export to a BIM platform to set information, then, export to GIS platform to set geographic coordinate and to complete the system, 
use an engine to integrate BIM, GIS and Virtual Reality (VR).

In order to select the Electromechanical software that was used to model the assets of the electric power substations, it was taken into account that it should be able to model parametric objects, making the model more accurate and reliable. In addition to geometric modeling, the system must be able to implement physical information (see Figure 7).

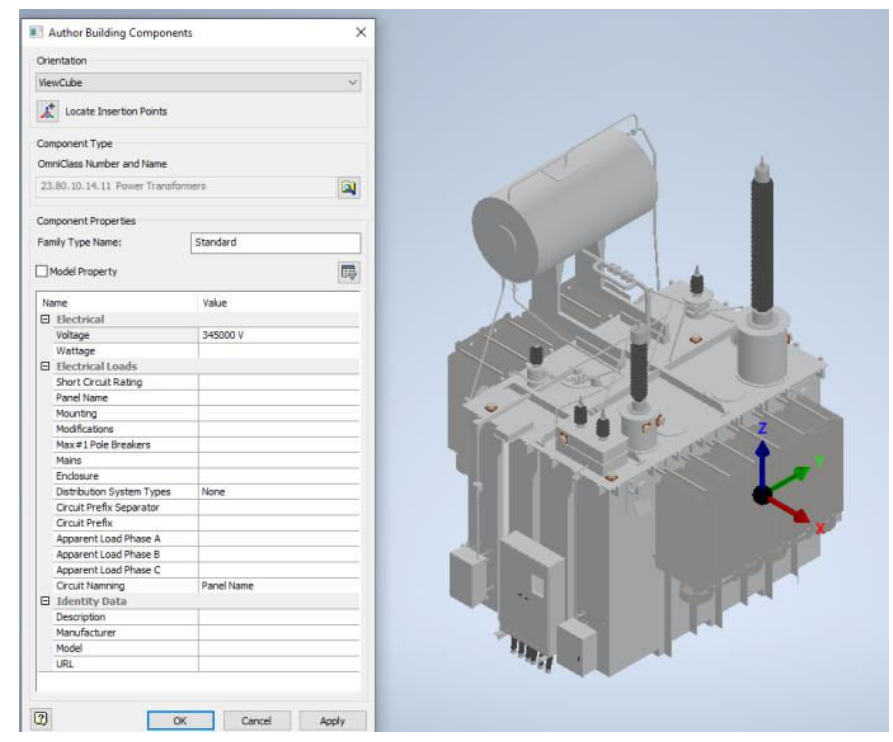

Fig. 7. Setting information in a 3D Model.

After the electromechanical software been selected the substation devices must be modeled with the level of detail necessary to each person who use the project. In that way was selected the information which will complete the $3 \mathrm{~d}$ model, according to the propose of this model.

However, to insert the non-geometrical information the best workflow was using a BIM software, where this kind of model will be replied more than one time in design phase. For use this as proof of concept was used the software Autodesk Revit.

As proof of concept the model selected was a power trans-former of $13.8 / 138 / 345 \mathrm{kV}$, of the substation of Mascarenhas de Moraes located at Sao Paulo state in Brazil. Instead starting modeling all substations was determined as a substation's part, to understand better the requisites of modeling. After creating some models

After modeling the electrical substation devices and associating the constructive information and created a library of models, with the main components of these and standardized the families for the BIM editor software. After importing these models, a base project is constructed within the hybrid system. Therefore, creating a generic database of the assets of the electric power substations. This database, when inserted in a pilot project, which has a georeferenced $\mathrm{CAD}$ file, will create unique characteristics for this object, obtaining more consistent information during the work phase, thus gaining advantages in decision making providing resources within the communication and a better understanding of the environment of an electric power substation (see Figure 8 and Figure 9).

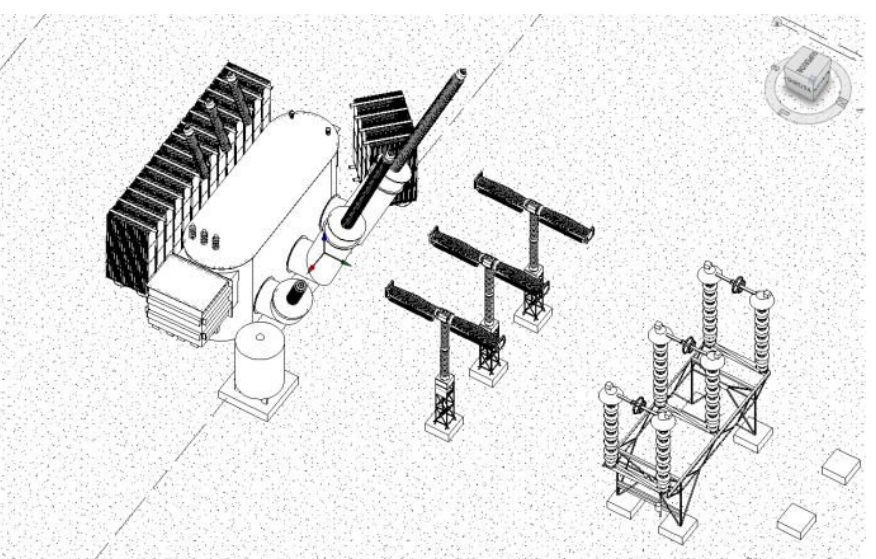

Fig. 8. BIM electrical arrangements in a Virtual Environment.

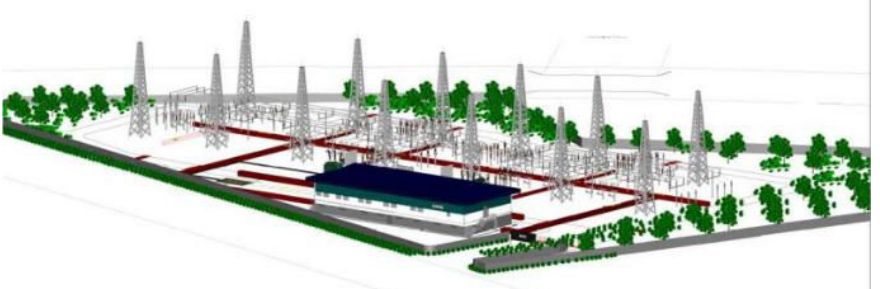

Fig. 9. 3D Electrical Substation [20]

The georeferenced CAD plant will be created from topo-logical and morphological analyzes of the soil, bringing with its information such as the ground level curves to be worked on thus creating a BIM plant to be incorporated into a single as-built interactive loaded of BIM and georeferenced models. Hence, this final model encompasses the information of a substation of electrical energy, such as the two-dimensional drawings (CAD), the documentation of the various disciplines involved in the design and execution of the project, a better estimation of materials, thus avoiding rework due to the integration of several projects and allowing access to direct metadata in the Virtual Environment (VE). Thus, this geo-referenced model will make the conditions of location and environment of the electric power substation more precise and pertinent, aiding in decision making. The association between these two platforms allows a more intuitive overview of the project, making them adherent to planning, design, construction, operation, and preventive and corrective maintenance, so that when applying these tools together the company will obtain result almost immediately, since the company will be equipped with information related to assets, arrangements, cabling, electronic components, thus optimizing processes and costs with labor, inputs, and processes. Also, this system allows an analysis in cases of need to relocate one equipment from one substation to another it is possible to find out more 
efficiently if it has the specifications will be in agreement with the arrangements of the substation that will receive the asset.

\section{Conclusion}

The association between BIM and GIS could improve the decision-making process, as both provide major information in a model, that information describes a spatial object. The BIM model is concerned with the building's level of details, and the semantic representation, and their inner components. On the other side, we have GIS technology who is a model with a digital representation of the earth's surface and its spatial object, without concern about how high detailed the model is. That association is already consolidated in architecture and civil engineering, and it is possible to evaluate advantages in urban and team management [3] [4]. Since these tools applied together to make it easier to make decisions.

Therefore, when applying this new project model, it is aimed at obtaining better communication among those in-volved in the works of electric power substations to facilitate better pricing, reduction of rework, reduction of costs, a quantification of more precise material, better documentation and better planning of preventive, corrective and predictive maintenance. Taking off more efficiently the maintenance teams, since, the assets in fields will be georeferenced.

However, to associate these two technologies, the workforce must be extremely specialized, requiring a multidisciplinary team, which includes from the areas of architecture, computing and electrical engineering.

\section{FUTURE WORKS}

According to the development of this work there is a gap in the junction of BIM models with Supervisory Control and Data Acquisition (SCADA).

\section{ACKNOWLEDGMENT}

Thanks to Capes and FAPEMIG (Foundation for Research Support of the State of Minas Gerais) for the financial support, Furnas Centrais Eletricas for their support in this work and the Laboratory of Computer Graphics of the Federal University of Uberlandia.

\section{REFERENCES}

[1] Kokorus, M., Eyrich, W., Zacharias, R. (2016, May). Innovative ap-proach to the substation design using Building Information Modeling (BIM) technology. In Transmission and Distribution Conference and Exposition (T\&D), 2016 IEEE/PES(pp. 1-5). IEEE.

[2] Akintoye, A., McIntosh, G., Fitzgerald, E. (2000). A survey of supply chain collaboration and management in the UK construction industry. European journal of purchasing \& supply management, 6(3-4), 159-168.

[3] Manzione, L. (2013). Proposic,ao ${ }^{\sim}$ de uma estrutura conceitual de gestao ${ }^{\sim}$ do processo de projeto colaborativo com o uso do BIM (Doctoral dissertation, Universidade de Sao ${ }^{\sim}$ Paulo).

[4] Almeida, F., \& Andrade, M. (2015). A Integrac, ao entre BIM e GIS como ferramenta de gestao urbana. VII Encontro de Tecnologia de Informac, ao e Comunicac, ao na Construc, ao (TIC 2015), Recife.

[5] Casey, M. J. (2008, October). Work in progress: How building infor-mational modeling may unify IT in the civil engineering curriculum. In Frontiers in Education Conference, 2008. FIE 2008. 38th Annual (pp. S4J-5). IEEE.

[6] AUTODESK (Estados Unidos). BIM 360 Design: Revit work-sharing and design collaboration software. 2018. Dispon'ivel

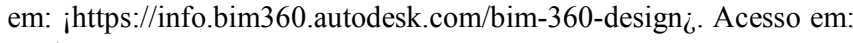
19 dez. 2018.

[7] Vasconcellos, A. S., \& Hernandes, L. (2015). Aplicac,ao de Metodologia BIM no Projeto e Construc,ao de Grandes Subestac, oes $\tilde{}$. Seminario Nacional de Produc, ao e transmissao ${ }^{\sim}$ de Energia Eletrica,' Foz do Iguac,u, PR.

[8] CATARINA, S. (2014). Caderno de Apresentac,ao de Projetos em BIM. Santa Catarina: Governo do Estado de Santa Catarina.

[9] Takim, R., Harris, M., \& Nawawi, A. H. (2013). Building Information Modeling (BIM): A new paradigm for quality of life within Architec-tural, Engineering and Construction (AEC) industry. Procedia-Social and Behavioral Sciences, 101, 23-32.

[10] Sullivan, J. M., Hall, R. H., Luna, R., Hilgers, M. G., Taylor, A. J., \& Buechler, M. R. (2004). Degree of scaffolding as learning object metadata: A prototype learning system design for integrating GIS into a civil engineering curriculum. Learning Technology, 6(2), 60-64.

[11] Song, Y., Wang, X., Tan, Y., Wu, P., Sutrisna, M., Cheng, J., \& Hampson, K. (2017). Trends and opportunities of BIM-GIS integration in the architecture, engineering and construction industry: a review from a spatio-temporal statistical perspective. ISPRS International Journal of Geo-Information, 6(12), 397.

[12] Hijazi, I., Donaubauer, A., \& Kolbe, T. (2018). BIM-GIS Integration as Dedicated and Independent Course for Geoinformatics Students: Merits, Challenges, and Ways Forward. ISPRS International Journal of Geo-Information, 7(8), 319.

[13] Esri. (2018). What is GIS? - Geographic Information System Mapping Technology. Retrieved December 27, 2018, from https://www.esri.com/en-us/what-is-gis/overview

[14] Irizarry, J., Karan, E. P., \& Jalaei, F. (2013). Integrating BIM and GIS to improve the visual monitoring of construction supply chain management. Automation in Construction, 31, 241-254.

[15] Peleg, K., \& Pliskin, J. S. (2004). A geographic information system simulation model of EMS: reducing ambulance response time. The American journal of emergency medicine, 22(3), 164-170.

[16] Irizarry, J., \& Karan, E. P. (2012). Optimizing location of tower cranes on construction sites through GIS and BIM integration. Journal of information technology in construction (ITcon), 17(23), 351-366.

[17] Esri and Autodesk - What's Next? (2018, February 01). Retrieved December 20, 2018, from Esri and Autodesk- What's Next?

[18] Geocoordinated BIM Modeling Benefits Build and Operate Projects." Between the Poles, Geoff Zeiss, 26 Oct. 2017, geospatial.blogs.com/geospatial/substation-design

[19] Tsai, C. F., Xiao, Y. T., Chen, H. S., Ye, Y. X., Wang, C. H., \& Liang, T. W. (2017, May). Integration of BIM and GIS to query management on pipeline of building-a case study of dormitory. In Applied System Innovation (ICASI), 2017 International Conference on (pp. 944-947). IEEE.

[20] Mijic, N., Sestic, M., \& Koljancic, M. (2017). CAD - GIS BIM integra-tion - case study of Banja Luka city center. In Advanced Technologies, Systems, and Applications (pp. 267-281). Springer, Cham.

[21] Tsai, C. F., Xiao, Y. T., Chen, H. S., Ye, Y. X., Wang, C. H., \& Liang, T. W. (2017, May). Integration of BIM and GIS to query management on pipeline of building-a case study of dormitory. In 2017 International Conference on Applied System Innovation (ICASI) (pp. 944-947). IEEE.

[22] Mijic, N., Sestic, M., \& Koljancic, M. (2017). CAD — GIS BIM integra-tion-case study of Banja Luka city center. In 
Advanced Technologies, Systems, and Applications (pp. 267-281). Springer, Cham.

[23] ESRI 2019, GIS in architecture, engineering and construction. viewed 10 May 2019 https://esriaustralia.com.au/gis-inarchitecture-engineering-and-construction.

\section{Creative Commons Attribution License 4.0} (Attribution 4.0 International, CC BY 4.0)

This article is published under the terms of the Creative Commons Attribution License 4.0

https://creativecommons.org/licenses/by/4.0/deed.en_US 